\title{
Apoptosis induced by microinjection of cytochrome $c$ is caspase-dependent and is inhibited by Bcl-2
}

\author{
Odd T. Brustugun ${ }^{1}$, Kari E. Fladmark ${ }^{1}$, Stein O. Døskeland ${ }^{1,3}$, \\ Sten Orrenius ${ }^{2}$ and Boris Zhivotovsky ${ }^{2}$ \\ 1 Department of Anatomy and Cell Biology, University of Bergen, Årstadveien 19, \\ $\mathrm{N}-5009$ Bergen, Norway \\ 2 Institute of Environmental Medicine, Division of Toxicology, Karolinska \\ Institutet, Box 210, S-171 77 Stockholm, Sweden \\ ${ }^{3}$ corresponding author: Department of Anatomy and Cell Biology, University of \\ Bergen, Årstadveien 19, N-5009 Bergen, Norway. \\ tel: +47 5558 63 76; fax: +47555863 60; e-mail: stein.doskeland@pki.uib.no
}

Received 26.11.97; revised 2.3.98; accepted 23.3.98

Edited by G. Melino

\begin{abstract}
Microinjection of cytochrome $c$ induced apoptosis in all the cell types we tested (IPC-81, Swiss 3T3, Clone 8 fibroblasts, NRK, H295, Y1, HEK 293). The apoptotic phenotype induced by injected cytochrome $c$ was characterized by externalization of phosphatidyl serine, cell detachment from substratum and from neighbor cells, and had the classic ultrastructural features of membrane budding, chromatin condensation and cell shrinkage. Depending on the cell type and concentration of cytochrome $c$, the induction of apoptosis was remarkably rapid. The development of apoptosis was prevented by the caspase inhibitor Z-VAD.fmk. Four of the cell types (Clone 8, Swiss 3T3, NRK, Y1) were transfected with bcl-2 and these all showed a markedly decreased sensitivity towards injected cytochrome $c$. Our data suggest that extramitochondrial cytochrome $c$ is a general apoptogen in cells with a functioning caspase system. They also indicate that, in preventing apoptosis, Bcl-2 acts not only at the level of regulation of cytochrome crelease from mitochondria, but can also interfere with caspase activation induced by cytochrome c microinjected directly into the cytoplasm.
\end{abstract}

Keywords: apoptosis; microinjection; cytochrome $c$; caspase; Bcl-2

Abbreviations: Apaf, apoptotic protease activating factor; TRITC, tetramethylrhodamine isothiocyanate; Z-VAD.fmk, Z-Val-Ala-DLAsp-fluoromethylketone

\section{Introduction}

Apoptosis is a distinct form of cell suicide, controlled by an internally encoded death program. Apoptotic cells are characterized by specific biochemical and morphological changes, including the activation of a proteolytic cascade leading to the cleavage of selective cytoplasmic and nuclear proteins, chromatin and RNA degradation, cell shrinkage and blebbing of cell membranes accompanied by the appearance of phosphatidyl serine on the outer surface of the plasma membrane.

The biochemical machinery involved in the killing and degradation of the cell is constitutively expressed. During the last few years the 'main players' in the induction and execution cascade of reactions in apoptotic cells were identified as a family of aspartic acid-specific cysteine proteases, the caspases (Alnemri et al, 1996). Overexpression of any of these proteases leads to apoptotic cell death. Moreover, mice deficient in caspase-3 have a striking defect in the extensive apoptosis that occurs during brain development. Peptide inhibitors of caspases can prevent apoptosis both in isolated cells and in in vivo models of development. Caspases are synthesized in a precursor form, and an apoptotic signal then converts the pro-caspase into the mature enzyme (for review see Zhivotovsky et al, 1997). At least two pro-caspases, procaspase- 8 and -1 , are activated via oligomerization-induced autoproteolysis (Yang et al, 1998). In contrast, procaspase-3, the best characterized executioner caspase, does not initiate activation in an autocatalytic manner. Activation of this enzyme requires an initiating first step cleavage, probably by other pre-existing cellular caspases, followed by a second autoproteolytic step.

In a search for biochemical components involved in caspase cascade activation, three apoptotic protease activating factors (Apaf $1-3$ ) were recently purified from a cell-free system based on cytosol from normal cells (Liu et al, 1996; Zou et al, 1997; Li P et al, 1997). One of these proteins (Apaf-2) was recognized as cytochrome c. Apaf-1 has a shared similarity with pro-domain of CED-3 and CED4 , and Apaf-3 was identified as a member of the caspase family, pro-caspase-9. The binding of Apaf-3 to Apaf-1 is dependent on the presence of cytochrome $c$ and dATP or ATP. This event leads to pro-caspase-9 activation. Activated caspase- 9 in turn cleaves and activates procaspase-3. Thus, cytochrome $c$ plays a cofactor role in the activation of the proteolytic cascade. Although holocytochrome $c$ is a mitochondrial protein, it has been demonstrated that following exposure of cells to apoptotic stimuli, cytochrome $c$ is rapidly released from mitochondria into the cytosol (Yang et al, 1997; Kluck et al, 1997a; Kharbanda et al, 1997). Additional experiments showed that cytochrome $c$ release in apoptotic cells can precede changes in mitochondrial membrane potential (Yang et al, 1997; Kluck et al, 1997a). It was further reported that antiapoptotic proteins of the $\mathrm{Bcl}-2$ family prevent this translocation of cytochrome $c$ from mitochondria to cytosol and thereby interfere with the subsequent activation of cytosolic caspases and apoptosis.

It has recently been demonstrated that addition of exogenous cytochrome $c$ to cytosolic extracts from normal 
cells induces caspase activation (Liu et al, 1996). Cytosolic caspase activation was only observed with intact holocytochrome $c$. Neither heat-denatured cytochrome $c$, nor enzyme-degraded cytochrome $c$ (microperoxidase-11, the heme group of cytochrome $c$ with amino acids 11-21) were able to substitute for holocytochrome $c$ (Kluck et al, 1997b; Hampton et al, 1998). Cytochrome P-450, cytochrome $b_{5}$, hemoglobin, biotinylated cytochrome $c$ and apo-cytochrome $c$ were also ineffective in this respect, showing the importance of the presence of unmodified cytochrome $c$ in this reaction (Hampton et al., 1998).

Based on these observations, several important questions were addressed in the present study. First, could high cytosolic concentrations of exogenous cytochrome $c$ induce apoptosis in most cells, making cytochrome $c$ a plausible general apoptosis inducer? Second, is the time course of the apoptotic process in this case compatible with the development of apoptosis induced by diverse stimuli? Finally, what effect might overexpression of $\mathrm{Bcl}-2$ cause in this situation? To address these questions we decided to microinject cytochrome $c$ into different types of cells in an attempt to mimic the release of endogenous cytochrome $c$ into the cytosol. Seven types of cells were injected: adrenocortical Y-1 tumor cells; human embryonal kidney HEK 293 cells; human adrenocortical tumor cell line H295; normal rat kidney (NRK) epithelial cells; mouse embryonal Swiss 3T3 fibroblasts; Clone 8 mouse embryonal fibroblasts; and rat promyelocytic IPC-81 leukemia cells. The type of cell death induced by microinjection was verified by co-staining with FITC-conjugated Annexin $\mathrm{V}$ and propidium iodide, as well as by electron microscopy. Four of the cell types were transfected with $b c /-2$ and the effect of the $\mathrm{Bcl}-2$ overexpression on the response to injected cytochrome $c$ was investigated. Our results indicate that injected cytochrome $c$ is able to induce apoptosis in various cell types and that this effect is caspase-dependent. Furthermore, in our experiments Bcl-2-overexpressing cells were protected from apoptosis induced by injected cytochrome $c$. A brief report of this study has recently appeared (Zhivotovsky et al, 1998).

\section{Results and Discussion}

\section{Microinjected cytochrome $c$ induces apoptosis in a number of cell types}

To investigate if microinjection of cytochrome $c$ is sufficient to kill cells and, if so, whether this is a general phenomenon, different types of cells were analyzed (various fibroblasts, leukemia cells, and epitheloid cells of normal and tumor origin).

Injected cytochrome $c$ appeared to be able to kill all cell types tested (Figures 1-5, Table 1). The cytochrome $c$ effect was specific since microinjection of the vehicle failed to induce cell death or any apparent changes in cellular morphology (shown for IPC-81 cells in Figure 1). Further, injection of biotinylated cytochrome $c$ (shown for Clone 8 fibroblasts in Figure 2) or apo-cytochrome $c$ (data not shown) induced no morphological signs of apoptosis. The inability to induce apoptosis by injection of modified cytochrome $c$ into intact cells is in accordance with the recent observation that biotinylated cytochrome $c$, in contrast to native cytochrome $c$, does not activate caspases in cytosolic extract (Hampton et al, 1998).

The first indications of cytochrome $c$-induced cell death were budding and partial or complete detachment of cells from plastic. Cells were considered apoptotic when they showed clear budding (Figures 1-5C). The kinetics of apoptosis induction were characterized in all cell types by a lag period followed by a first order accumulation of apoptotic cells (shown for Y1 cells, Swiss 3T3 cells and NRK cells in Figures 3-5). The estimated intracellular concentration of cytochrome $c$ in these experiments was $20 \mu \mathrm{M}$ (Mellgren et al, 1993). A difference in lag phase (5$40 \mathrm{~min}$ ) was related to the sensitivity of different cells to undergo apoptosis. The relatively short lag period between cytochrome $c$ injection and morphological signs of apoptosis suggests that mitochondrial leakage of cytochrome $c$ into the cytoplasm might also rapidly activate apoptosis in the intact cell. Thus, it appears likely that the control of cytochrome $c$ release from mitochondria represents a critical step in the apoptotic process.
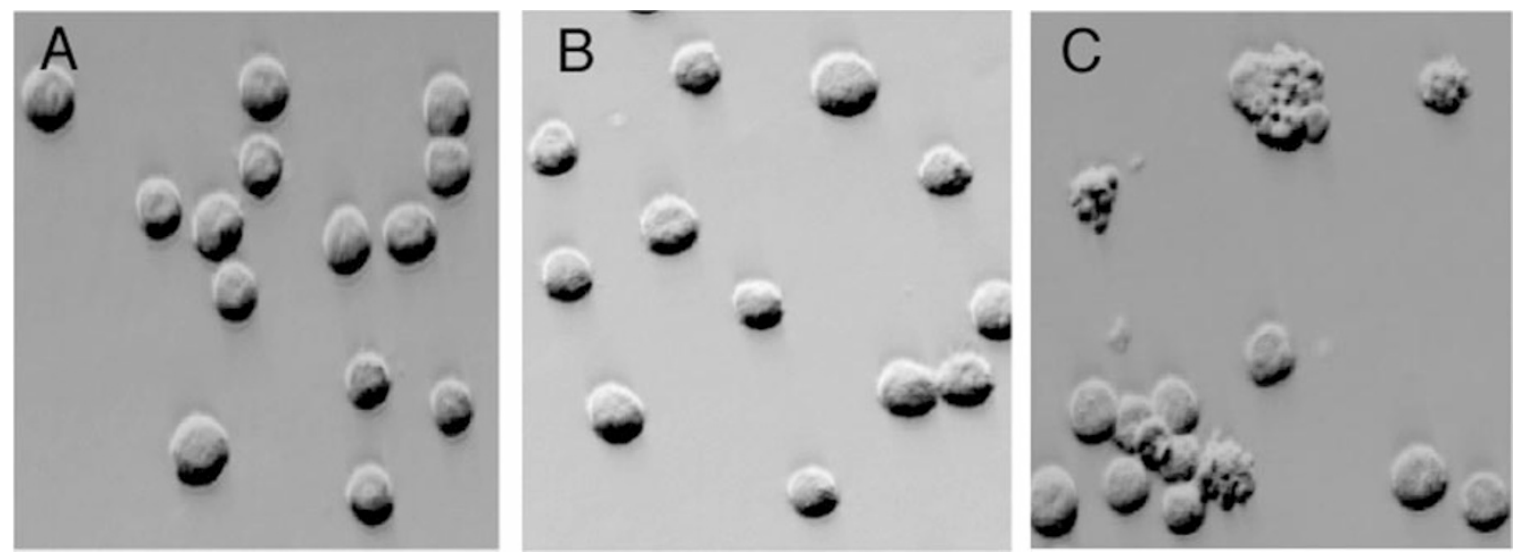

Figure 1 The appearance of IPC-81 cells $2 \mathrm{~h}$ after microinjection of cytochrome $c$. (A) Control (non-injected) cells. (B) Cells injected with water. (C) Cells injected with $20 \mu \mathrm{M}$ cytochrome $c$ dissolved in water. Magnification $300 \times$ 
The first order rate constant $\left(K_{\text {apop }}=\ln 2 / t_{1 / 2}\right)$ of apoptosis induction in these experiments was $2.8 / \mathrm{h}$ for $\mathrm{Y} 1,1.4 / \mathrm{h}$ for Swiss 3 T3 fibroblasts, and $0.54 / \mathrm{h}$ for NRK cells. One hour after injection, apoptotic morphology was seen in $79 \pm 4.0 \%$ of $\mathrm{Y} 1$ cells, $70 \pm 8.3 \%$ of Swiss $3 \mathrm{~T} 3$ fibroblasts, $31 \pm 5.1 \%$ of NRK cells, $22 \pm 1.3 \%$ of IPC- 81 cells, $36 \pm 3.0 \%$ of $\mathrm{H} 295$ cells, $46 \pm 6 \%$ of HEK 293 cells, and more than $99 \%$ of the Clone 8 cells. Thus, microinjection of cytochrome $c$ was sufficient to kill all cell types tested.
To confirm the morphological characteristics of apoptosis, the injected cells were analyzed by transmission electron microscopy. The ultrastructure of cells injected with cytochrome $c$ (Figure 6) was characterized by surface protrusions, some of which became pinched off to form apoptotic bodies while the plasmalemma remained intact. The cytoskeleton was dramatically altered, and in addition to gross morphological changes, clustering of actin filaments was observed (Figure 6B). The mitochondria
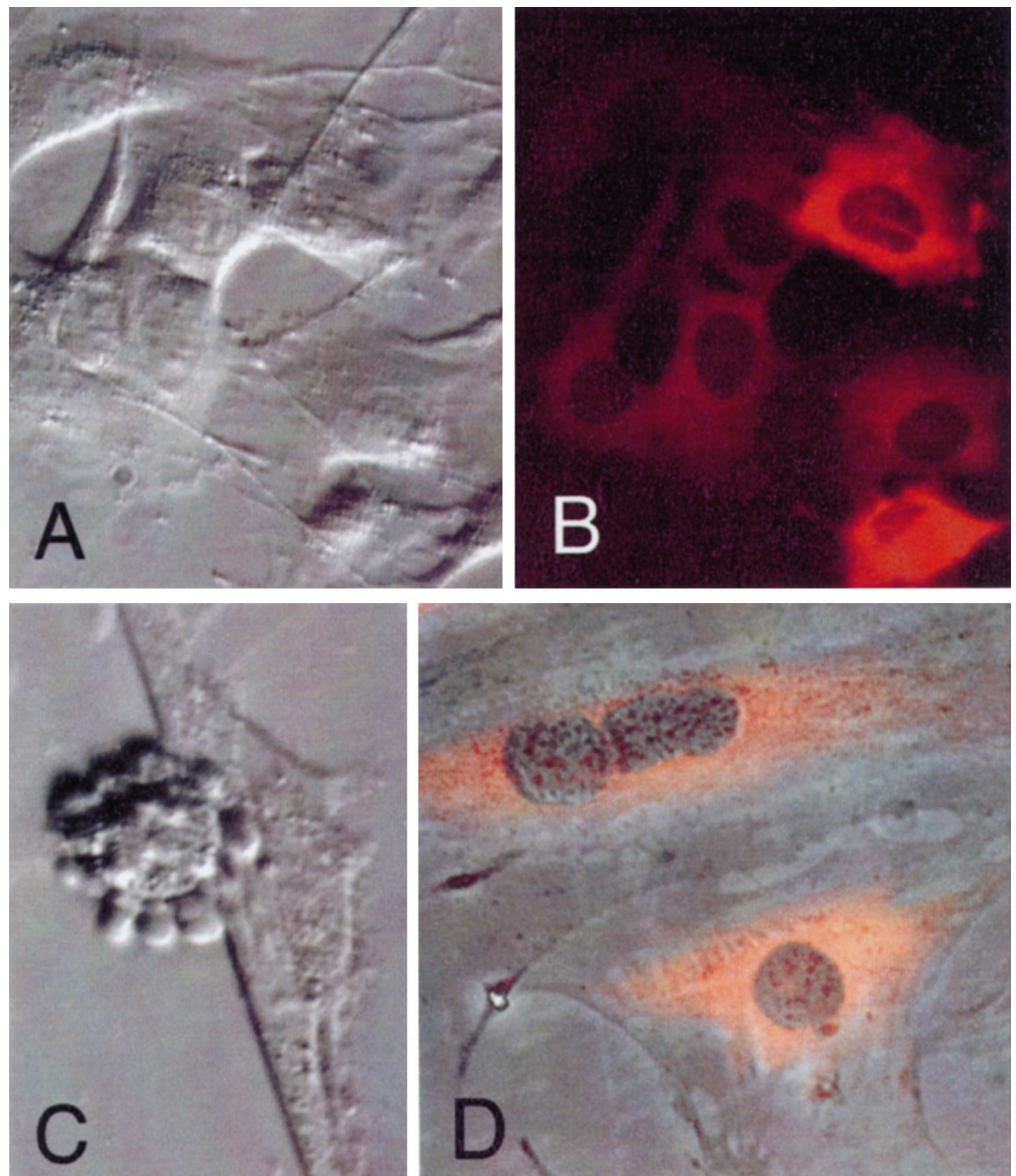

Figure 2 Comparison of Clone 8 cells injected with biotinylated and non-biotinylated cytochrome $c$, and of wild-type and bcl-2 transfected Clone 8 cells injected with cytochrome $c$. (A) Wild-type cells injected with TRITC-dextran and $25 \mu \mathrm{M}$ biotinylated cytochrome $c$. Magnification: $300 \times$. (B) Fluorescent micrograph of the same field as in panel A. Magnification $300 \times$. (C) Wild-type cells injected with TRITC-dextran and $2 \mu \mathrm{M}$ cytochrome $c$. Magnification $500 \times$. (D) $b c l-2$ transfected Clone 8 cells injected with TRITC-dextran and $2 \mu \mathrm{M}$ cytochrome $c$ viewed under combined phase and fluorescent microscopy. Magnification $400 \times$ 


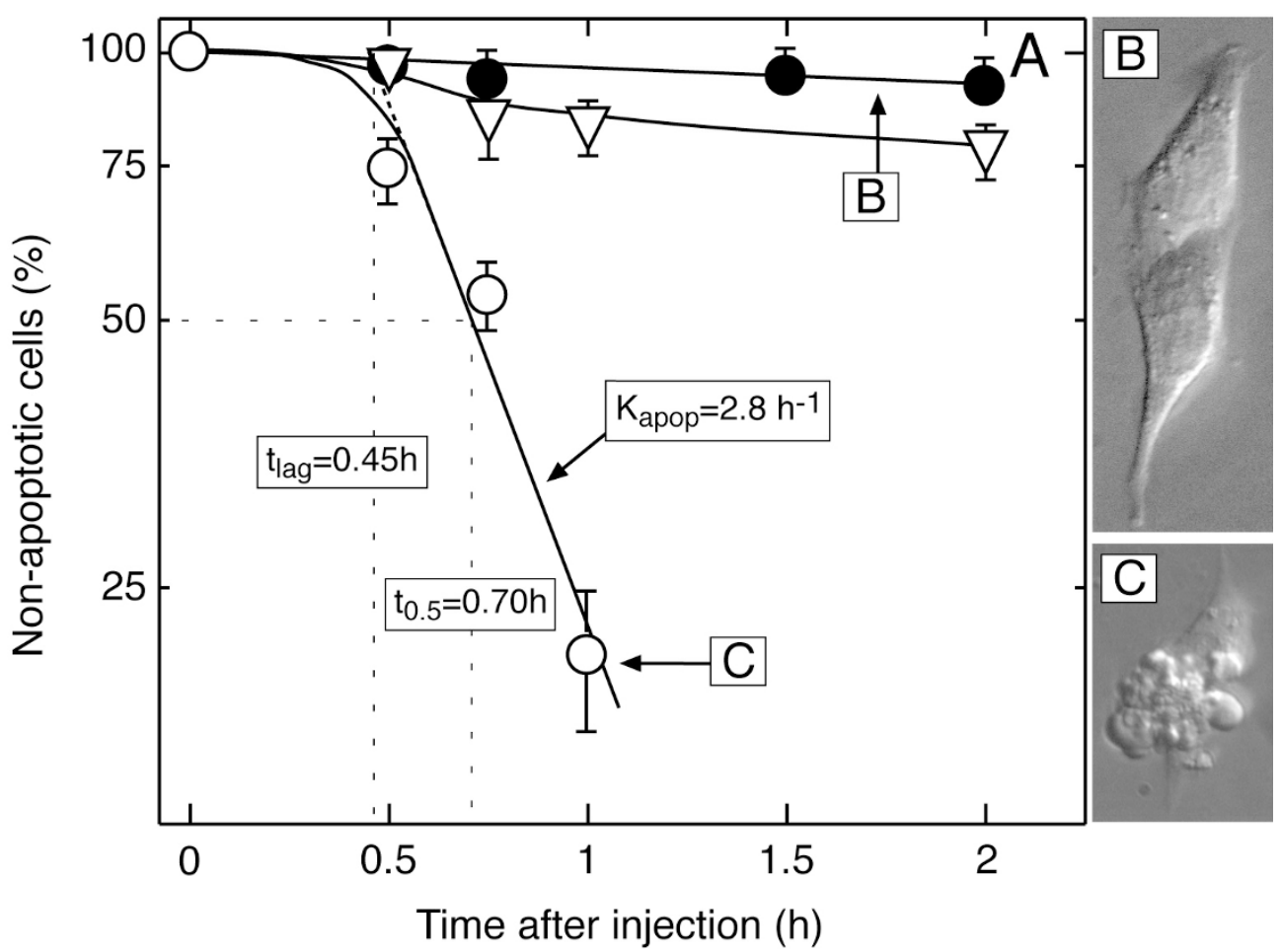

Figure 3 Time course of apoptosis development in wild-type and bcl-2 transfected $Y 1$ adrenocortical cells injected with cytochrome $c$. (A) Wild-type cells injected with $20 \mu \mathrm{M}$ cytochrome $c$ without $(O)$ and with $(\mathbf{O})$ preincubation with caspase inhibitor $(20 \mu \mathrm{M}$ Z-VAD.fmk), and bcl-2 transfected cells injected with $20 \mu \mathrm{M}$ cytochrome $c(\nabla)$. Note the semilogarithmic nature of the graph and the insets showing the lag time $(0.45 \mathrm{~h})$ before the wild-type cell population started to undergo apoptosis after injection (see the Materials and Methods section for further details). (B) Wild-type Y1 cells preincubated with Z-VAD.fmk 105 min after injection of cytochrome $c$. Magnification: $400 \times$. (C) Wild-type $\mathrm{Y} 1$ cells $1 \mathrm{~h}$ after injection with cytochrome $c$. Magnification $400 \times$

were redistributed within the cytoplasm, presumably secondary to cytoskeletal alterations. Otherwise, the mitochondrial ultrastructure appeared normal. These structural changes were similar to those described in cells undergoing apoptosis in response to diverse stimuli (Gjertsen et al, 1994). In addition to electron microscopy, cells microinjected with cytochrome $c$ were studied by costaining of cells with FITC-conjugated Annexin $V$ and propidium iodide. Cells dying in response to microinjection of cytochrome $c$ became Annexin V-positive, demonstrating that microinjection of cytochrome $c$ is also associated with phosphatidyl serine exposure on the cell surface. The plasma membrane remained intact, since the cells excluded propidium iodide and trypan blue (data not shown). In cells left for hours after injection, or in cells deliberately injected under supra-optimal pressure, necrosis was observed as evidenced by internalization of propidium iodide in addition to positive staining with Annexin V (data not shown).

\section{Z-VAD.fmk inhibits cytochrome $c$-induced apoptosis}

It has previously been shown that cytochrome $c$ in cellfree extracts triggers caspase activation (Liu et al, 1996). To determine if apoptosis induced by microinjection of cytochrome $c$ also involves the caspase-mediated path- way, cells were preincubated for 30-60 min with $20 \mu \mathrm{M}$ of the caspase inhibitor Z-VAD.fmk. For all cell types except Clone 8 , less than $13 \%$ of the pretreated cells became apoptotic and remained at the same level of apoptosis for more than $3 \mathrm{~h}$ after injection of $20 \mu \mathrm{M}$ cytochrome $c$ (Figures 3-5; Table 1). The Clone 8 cells were particularly sensitive to cytochrome $c$ and were injected with significantly lower concentrations $(2-10 \mu \mathrm{M})$ of this protein. Z-VAD.fmk was also effective in Clone 8 cells injected with these low concentrations of cytochrome $c$ (Table 1). Thus, our results indicate that injected cytochrome $c$ is able to induce caspase-dependent apoptosis. This is compatible with the proposed mechanism (Li $\mathrm{P}$ et al, 1997) that cytochrome $c$ released from mitochondria can promote pro-caspase- 9 processing and thereby the subsequent activation of the caspase cascade involved in the cellular execution machinery.

\section{$\mathrm{Bcl}-2$ overexpression prevents cell death after cytochrome $c$ injection}

In many experimental models overexpression of $\mathrm{Bcl}-2$, or its close family member Bcl- $x_{\mathrm{L}}$, protects cells from apoptosis (for review see Reed, 1997). It has been suggested that the role of $\mathrm{Bcl}-2$ protection is linked to its mitochondrial location and the prevention of release of cytochrome $c$ into the cytoplasm (Yang et al, 1997; Kluck 


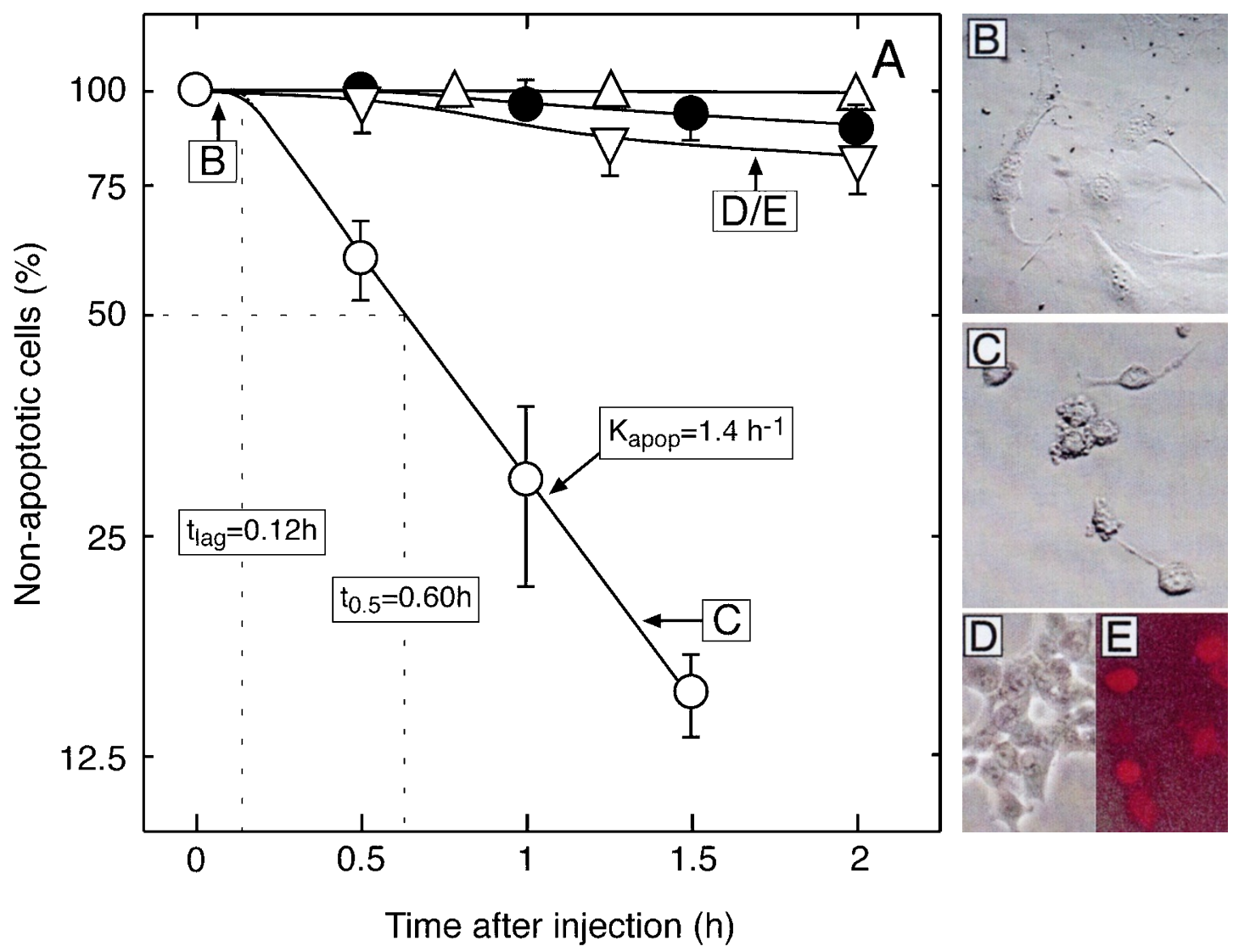

Figure 4 Time course of apoptosis development in wild-type and $b c l-2$ transfected Swiss 3 T 3 cells injected with $20 \mu \mathrm{M}$ cytochrome $c$. (A) Corresponds to that for Y1 cells in Figure 3, except that an additional experiment is shown in which the 3 T3 cells were injected with $20 \mu \mathrm{M}$ biotinylated cytochrome $c(\triangle)$. (B) Wild-type $3 T 3$ cells about $5 \mathrm{~min}$ after injection of cytochrome $c$, i.e. before onset of apoptosis. (C) Wild-type 3 T3 cells 90 min after injection of cytochrome $c$. (D) bcl-2 transfected cells $2 \mathrm{~h}$ after injection of $20 \mu \mathrm{M}$ cytochrome $c$. (E) Fluorescent micrograph of the same field as in $\mathbf{D}$ to demonstrate that all cells were successfully injected. Magnification of all photos: $200 \times$

et al, 1997a). This idea was supported by experimental data obtained from a mammalian cell-free system and in whole cells treated with apoptosis-inducing agents (Yang et al, 1997). In these systems, Bcl-2 was not able to prevent the effect of cytochrome $c$, once it had been released from the mitochondria. We had therefore expected that microinjected cytochrome $c$ should act equally well in triggering apoptosis whether cells overexpressed Bcl-2 or not. Surprisingly, in our experiments overexpression of $\mathrm{Bcl}-2$ significantly delayed cell death even when cytochrome $c$ was injected into the cytosol (Figures 3-5). Moreover, the cells did not undergo an incomplete or partial apoptosis as judged by their normal morphology after injection with cytochrome $c$ (Figures 2D, $4 \mathrm{D}$ and $\mathrm{E}, 5 \mathrm{~B})$. To ascertain that the $b c /-2$ transfected cells were adequately injected, cytochrome $c$ was coinjected with TRITC-dextran and successfully injected cells were scored by fluorescence microscopy. The same percentage $(60-99 \%)$ of successfully injected cells was achieved in wild-type and bcl-2 transfected cells. Figures $2 \mathrm{D}$ and $4 \mathrm{E}$ show non-apoptotic $b c /-2$ transfected cells co-injected with fluorescent TRITCdextran and cytochrome $c$. Cells were fluorescent- positive and morphologically normal for more than $24 \mathrm{~h}$ after injection. It is important to note that the protective effect of Bcl-2 was dependent on the level of free cytoplasmic cytochrome $c$ (Table 2). By increasing the concentration of cytochrome $c$ progressively, the protection from death by overexpression of $\mathrm{Bcl}-2$ could be overcome (data shown for Clone 8 cells in Table 2).

Several explanations can be offered for our unexpected observation. First, $\mathrm{Bcl}-2$ and other $\mathrm{Bcl}-2$-like proteins are located not only in the mitochondrial outer membrane but also in other organelles (Hockenbery et al, 1990) - hence the anti-apoptotic property might be due to an action outside the mitochondria. In fact, it has been shown that $\mathrm{Bcl}-2 / \mathrm{Bcl}-\mathrm{x}_{\mathrm{L}}$ and pro-caspase-8 are cooperatively associated with the Bap31 complex in the endoplasmic reticulum ( $\mathrm{Ng}$ and Shore, 1998). Based on this observation, the authors suggested that 'this complex in the ER might cooperate with events in the mitochondria to control proximal and distal steps in a Bcl-2-regulated caspase cascade'. Second, Bcl-2 may also be a member of the 'apoptosome' complex and prevent cell death by directly binding to Apaf-1/Apaf-2/Apaf-3, or it may prevent the formation of an active Apaf 1-3 complex. This would be 

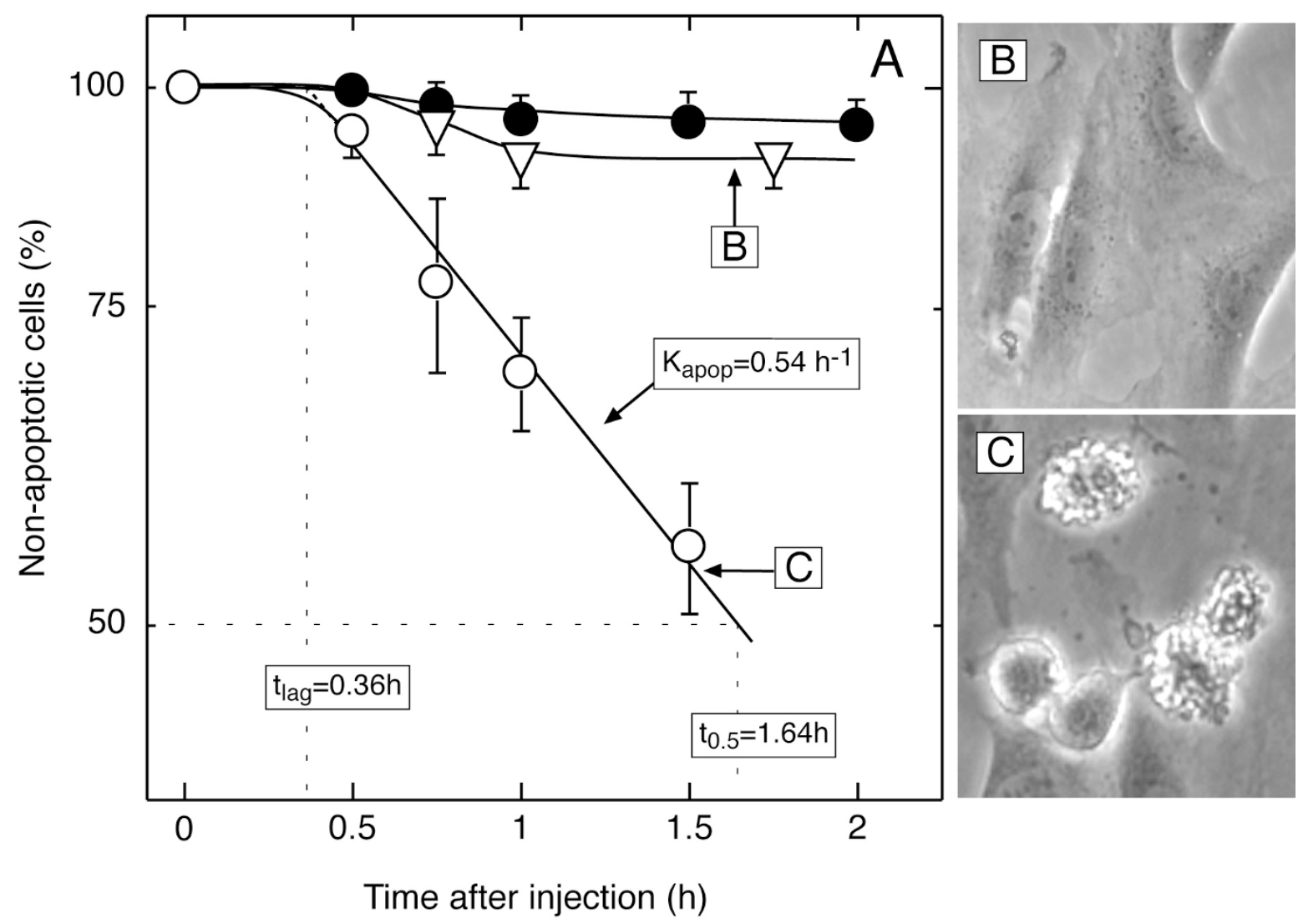

Figure 5 Time course of apoptosis development in wild-type and bcl-2 transfected NRK cells injected with $20 \mu \mathrm{M}$ cytochrome $c$. (A) Corresponds to that for Y1 cells in Figure 3. (B) bcl-2 transfected NRK cells 105 min after injection of $20 \mu \mathrm{M}$ cytochrome $c$. (C) Wild-type NRK cells 90 min after injection of $20 \mu \mathrm{M}$ cytochrome $c$. Magnification $400 \times$

analogous to the nematode system, where CED-9 binds to the CED-3/CED-4 complex to prevent CED-3 activation (Hengartner, 1997, 1998). Third, it has been reported that cytochrome $c$ binds to $\mathrm{Bcl}-\mathrm{x}_{\mathrm{L}}$ (Kharbanda et al, 1997), and it seems reasonable that $\mathrm{Bcl}-2$ may exert a similar quenching effect outside the mitochondria. Fourth, Bcl-2 targets several proteins, including the protein kinase Raf-1, to mitochondria (Wang et al, 1996a). It has been shown that a Bcl-2 interacting protein, Bag-1, binds to and activates the kinase Raf-1 (Wang et al, 1996b). Moreover, Bag-1 modulates the chaperone activity of Hsp70 (Takayama et al, 1997). Thus, it seems possible that when $\mathrm{Bcl}-2$ is overexpressed, it may act, perhaps together with other anti-apoptotic proteins (Bag-1?), as a transporter for cytochrome $c$ back to mitochondria (Scaife, 1966). The capacity of the Bcl-2 to facilitate this putative re-entry of cytochrome $c$ into mitochondria could simply be overloaded. This might explain the fact, that high concentrations of injected cytochrome $c$ overcome the Bcl-2 defense (Table 2).

In addition to serving as a source for cytochrome $c$ release, the importance of mitochondria for apoptosis is underscored by the co-localization of pro-apoptotic and anti-apoptotic proteins to the outer mitochondrial membrane (Hockenbery et al, 1990); the requirement of ATP for several critical steps in the apoptotic process (Nicotera and Leist, 1997; Tsujimoto, 1997); and the disruption of mitochondrial physiology, including swelling and opening of mitochondrial megachannels (so-called permeability transitions, PT) during apoptosis (Kroemer, 1997; Vander Heiden et al, 1997). The mechanism by which cytochrome $c$ is released from mitochondria is still unknown. In a recent publication (Vander Heiden et al, 1997), the alterations in mitochondrial physiology that follow apoptotic stimuli were investigated to determine which, if any, of them could be affected by Bcl- $x_{L}$. The authors concluded that $\mathrm{Bcl}-\mathrm{x}_{\mathrm{L}}$ promoted cell survival by regulating the membrane potential and volume homeostasis of mitochondria. Consistent with their observation, $\mathrm{Bcl}-\mathrm{x}_{\mathrm{L}}$ was not able to inhibit apoptosis induced by microinjection of cytochrome $c$ in 293 cells (Duckett et al, 1998). On the other hand, it has recently been shown that microinjection of cytochrome $c$ into MCF-7 cells did not overcome the anti-apoptotic effect of $\mathrm{Bcl}-\mathrm{x}_{\mathrm{L}}$, suggesting that the ability of $\mathrm{Bcl}-\mathrm{x}_{\mathrm{L}}$ to inhibit cell death cannot be due solely to the inhibition of cytochrome $c$ release from mitochondria ( $\mathrm{Li} \mathrm{F}$ et al, 1997). Moreover, it is quite possible that $\mathrm{Bcl}-2$ and $\mathrm{Bcl}-\mathrm{x}_{\mathrm{L}}$ do not use exactly the same pathway for their anti-apoptotic effect. In fact, ectopic expression of $\mathrm{Bcl}-2$, but not $\mathrm{Bcl}-\mathrm{x}_{\mathrm{L}}$ rescues $\mathrm{B}$ 
Table 1 The effect of caspase inhibitor on cytochrome $c$-induced apoptosis

\begin{tabular}{lcccc}
\hline & Cytochrome c & \multicolumn{2}{c}{ Apoptotic cells $(\% \pm$ SEM) } \\
Cell type & $(\mu$ M in cell) & No Z-VAD & 20 $\boldsymbol{\mu M}$ Z-VAD & $\mathbf{n}$ \\
\hline Clone 8 & 2 & $23 \pm 6.6$ & $4.6 \pm 1.5$ & 3 \\
Clone 8 & 4 & $40 \pm 8.9$ & $7.2 \pm 0.3$ & 3 \\
Clone 8 & 10 & $96 \pm 2.9$ & $76 \pm 7.7$ & 3 \\
Clone 8 & 20 & $99 \pm 0.3$ & n.d. & 3 \\
H295 & 20 & $36 \pm 3.0$ & $12 \pm 3.0$ & 3 \\
HEK 293 & 20 & 46 & 6.8 & 2 \\
\hline
\end{tabular}

Clone 8 fibroblasts, H295 adrenocortical cells and HEK 293 kidney cells were injected with TRITC-dextran and cytochrome $c$ to give the intracellular concentrations as indicated. $20 \mu \mathrm{M}$ Z-VAD.fmk was added 30-60 min before injections. Cells were scored for apoptotic morphology 90 min after injections. The standard error of the mean (SEM) and the number of separate experiments $(n)$ are indicated
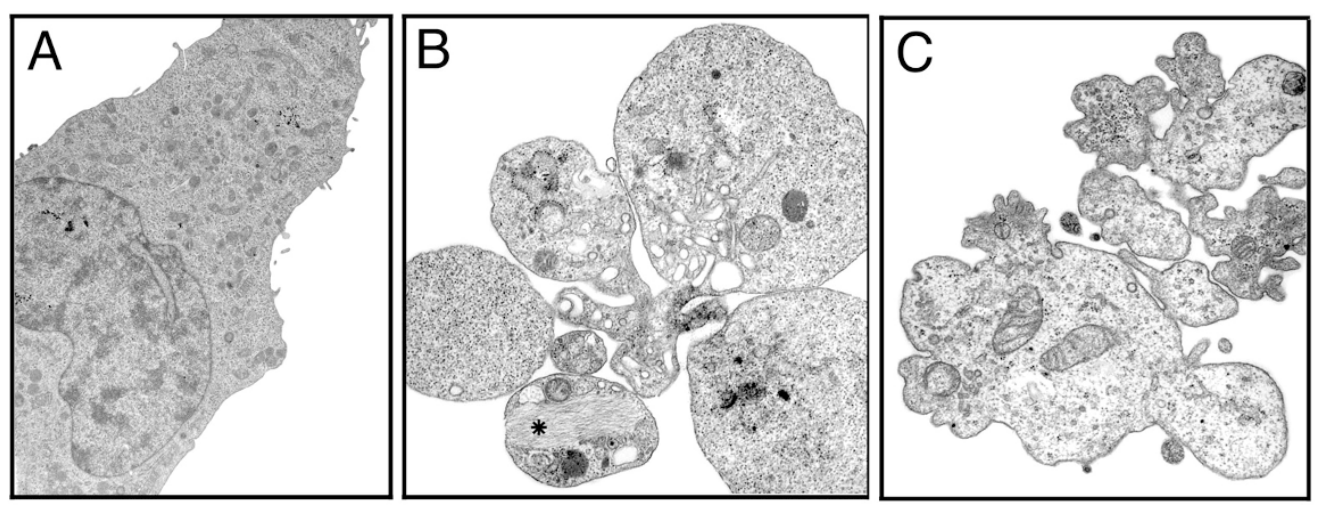

Figure 6 Electron micrographs of NRK cells fixed $2 \mathrm{~h}$ after injection with water (A) or $20 \mu \mathrm{M}$ cytochrome $c$. (B, C). Panel B shows a cell in a moderately advanced stage of apoptosis and panel $\mathbf{C}$ shows a cell in a later stage of apoptosis. Note the condensed assembly of microfilaments in panel $\mathbf{B}$ (indicated by asterix). Magnification: A: $\times 3.200$, B: $\times 10.250$, C: $\times 12.500$

Table 2 The concentration dependence of cytochrome $c$ action in wild-type and bcl-2 transfected cells

\begin{tabular}{lccc}
\hline Cell type & $\begin{array}{c}\text { Cytochrome c } \\
(\mu \mathbf{M} \text { in cell) }\end{array}$ & $\begin{array}{c}\text { Apoptotic cells } \\
(\% \pm \mathbf{S E M})\end{array}$ & $\mathbf{n}$ \\
\hline Clone 8 & 2 & $23 \pm 6.6$ & 3 \\
Clone 8-bcl2 & 2 & $0 \pm 0$ & 3 \\
Clone 8 & 4 & $40 \pm 8.9$ & 3 \\
Clone 8-bcl2 & 4 & $4.7 \pm 0.8$ & 5 \\
Clone 8 & 10 & $96 \pm 2.9$ & 3 \\
Clone 8-bcl2 & 10 & $78 \pm 9.1$ & 3 \\
Clone 8 & 20 & $99 \pm 0.3$ & 3 \\
Clone 8-bcl2 & 20 & $96 \pm 1.9$ & 3 \\
\hline
\end{tabular}

The experiments were conducted in parallel with those shown in Table 1 (data for wild-type cells are the same). For experimental details, see the legend to Table 1

cells from Fas-mediated apoptosis (Alam et al, 1997). However, further experimentation is required to resolve these apparent discrepancies.

There is an additional, fifth, possibility to explain the $\mathrm{Bcl}-2$ protective effect. The injection of cytochrome $c$ could initiate the 'circle of death' proposed by Hengartner (1998), in which initially activated caspases could promote further mitochondrial cytochrome $c$ release, leading to a second loop of caspase activation and apoptosis. This mechanism would also be compatible with the finding that $\mathrm{Bcl}-2$ protects only against moderate amounts of injected cytochrome $c$. In fact, it has been shown that in apoptotic cells cleavage of $\mathrm{Bcl}-2$ by caspases leads to conversion of $\mathrm{Bcl}-2$ to a Bax-like death effector protein (Cheng et al., 1997). It is likely that cleavage of mitochondrial $\mathrm{Bcl}-2$ can also promote the release of cytochrome $c$. In this case the overexpression of Bcl-2 might act not only by blocking the cytochrome $c$ release, but also downstream via (an) unknown mechanism(s), possibly by enhancing cellular anti-oxidant defence or by regulating the flow of different ions, including $\mathrm{Ca}^{2+}$, across the endoplasmic reticulum membrane (He et al., 1997). In fact, in cells transiently transfected with bax (pro-apoptotic homologue of $b c /-2$ ), Bax was localized to mitochondria and promoted the release of cytochrome $c$. In this case the overexpression of $\mathrm{Bcl}-2$ failed to prevent Bax-induced cytochrome $c$ release, however, it did increase the survival of cells with significant amounts of cytochrome $c$ in the cytoplasm (Rosse et al, 1998). These data, as well as ours, suggest that $\mathrm{Bcl}-2$ might have other functions than the prevention of mitochondrial cytochrome $c$ release.

Thus, it appears that cytochrome $c$-induced apoptosis can be prevented by $\mathrm{Bcl}-2$ not only at the level of its release from mitochondria, but also downstream of this release, possibly by one of the mechanisms described above. Work is in progress in our and other laboratories to investigate the precise mechanism of the protective effect of the Bcl-2 family of proteins in apoptosis. 


\section{Materials and Methods}

\section{Materials}

Bovine cytochrome $c$, hexa-biotinylated cytochrome $c$, geneticin and TRITC-labeled dextrane were obtained from Sigma (St Louis, MO, USA). Z-VAD.fmk was from Bachem (Bubendorf, Switzerland). SuperFect transfection agent was obtained from Qiagen $\mathrm{GmbH}$ (Hilden, Germany). Expression vector for bcl-2 (p442) was a kind gift from $\mathrm{Dr}$ Timothy McDonnell (MD Anderson Cancer Center, Houston, TX, USA). Bi-biotinylated cytochrome $c$ was prepared in our laboratory by David $\mathrm{H}$ Burgess.

\section{Cell culture and microinjection}

Normal rat kidney NRK cells, Swiss 3 T3 fibroblasts, mouse Y1 adrenocortical tumor cells, human embryonal kidney HEK 293 cells, Clone 8 embryonal mouse fibroblasts and IPC-81 promyelocytic leukemia cells were grown in Dulbecco's modified Eagle's medium (DMEM) containing 10\% FCS, penicillin $(100 \mathrm{lU} / \mathrm{ml})$ and streptomycin $(100 \mu \mathrm{g} / \mathrm{ml})$. The human adrenocortical tumor cell line H295 was cultured in a 1:1 mixture of DMEM and Ham's F-12 medium (GibcoBRL, Gaitherburg, MD, USA) supplemented with insulin $(6.25 \mu \mathrm{g} / \mathrm{ml})$, transferrin $(6.25 \mu \mathrm{g} / \mathrm{ml})$, selenium $(6.25 \mathrm{ng} / \mathrm{ml})$, linoleic acid $(5.35 \mu \mathrm{g} /$ ml; ITS plus, Collaborative Research, Bedford, MA, USA), $2 \%$ NuSerum (Collaborative Research, Bedford, MA, USA) and antibiotics. All cell types were cultured in $9.8 \mathrm{~cm}^{2}$ dishes with grid patterns forming $4 \mathrm{~mm}^{2}$ squares. Microcapillaries (type BF100-10, 1.00/0.78) and puller (Model P-87) were from Sutter Instrument Co. (Novato, CA, USA). The micromanipulator (Eppendorf 5171), microinjector (Eppendorf 5246), and an incubator providing $5 \% \mathrm{CO}_{2}$ and $37^{\circ} \mathrm{C}$ were mounted on an inverted Nikon Diaphot 300 microscope. NRK, Y1, Swiss 3T3, Clone 8, HEK 293, H295 and the corresponding bcl-2-transfected cells were seeded at 10000 cells $/ \mathrm{cm}^{2}$ and were injected $24 \mathrm{~h}$ after seeding. IPC81 cells to be injected were seeded at $3 \times 10^{4} / \mathrm{cm}^{2}$ in dishes precoated with fibronectin $\left(1 \mu \mathrm{g} / \mathrm{cm}^{2}\right)$. After seeding, the cells were treated with $100 \mathrm{nM}$ of the phorbol ester TPA to further improve cell attachment. Cells were injected $4-8 \mathrm{~h}$ after seeding.

Cytochrome $c$ was routinely co-injected with TRITC-dextran (to $0.1 \mu \mathrm{g} / \mu$ l intracellular concentration) to detect positively-injected cells with a fluorescence microscope, and was delivered in $\mathrm{H}_{2} \mathrm{O}$. Control injections were done with TRITC-dextran in $\mathrm{H}_{2} \mathrm{O}$ alone. There was no enhancement or attenuation of the effect of injected cytochrome whether TRITC-dextran was present or not and whether the cytochrome was dissolved in physiological buffer or in water. Optimal injections were obtained with capillary pipettes with a tip diameter of less than $0.3 \mu \mathrm{m}$, which were made shortly before the experiment. Pipettes were loaded by retrograde filling. The injected volume was estimated as previously shown (Mellgren et al, 1993) to be close to $2 \%$ of the cellular volume, corresponding to a 50 -fold dilution of injected material. The inhibitor of caspase activity, Z-VAD.fmk, was dissolved in dimethylsulfoxide (DMSO) and added to the culture medium $30-$ $60 \mathrm{~min}$ before the injections. The final concentration of DMSO was less than $0.5 \%$ and $0.5 \%$ DMSO by itself did not affect the cells.

Injections were performed in 50-150 cells for each experimental condition in each experiment, and data is presented as the average from at least four experiments, unless otherwise indicated.

\section{Transfections}

Y1 cells were transfected using the calcium phosphate protocol. Swiss 3T3 and NRK were transfected using the SuperFect agent from Qiagen, as described in the protocol from the manufacturer. The transfected cells were selected with neomycin $1 \mathrm{mg} / \mathrm{ml}$ or geneticin for several weeks. Bcl-2 expressing cells were almost completely resistant against anti-Fas- and daunorubicin-induced apoptosis, while non-transfected or mock-transfected cells treated with anti-Fas or daunorubicin died within 30-36 h (not shown). Some cultures were co-transfected with lacZ-containing plasmid for evaluation of transfection efficiency. Cells were microinjected $24 \mathrm{~h}$ following transfection with the fluorogenic $\beta$-galactosidase substrate CMFDG (Brustugun et al, 1995). The bcl-2 transfected Clone 8 cells were a kind gift from R. Ahlgren and T. Sandal at the Department of Anatomy and Cell Biology, University of Bergen.

\section{Evaluation of apoptotic morphology and determination of rate constants for apoptosis development}

For routine assessment of apoptosis, cell morphology was evaluated by inverted phase microscopy using phase and Nomarski optics. Apoptotic cells of all cell types were easily discriminated from nonapoptotic (both normal and necrotic) cells by the appearance of surface protrusions, and in some experiments cells were treated with FITC-conjugated Annexin $V$ to verify apoptotic cells. In brief, cells were exposed to $5 \mu \mathrm{g} / \mathrm{ml}$ FITC-conjugated Annexin $\mathrm{V}$ and counter-stained with $5 \mu \mathrm{g} / \mathrm{ml}$ propidium iodide. Cells were scored under UV light using filter sets as for FITC-staining, containing a long pass filter for simultaneous detection of propidium iodide.

When the decrease of normal cells after cytochrome $c$ injection was plotted semilogarithmically against time (Figures 3-5), a near rectilinear curve resulted. This allowed the determination of the rate constant for the transition from normal to apoptotic phenotype $\left(\mathrm{K}_{\mathrm{apop}}\right)$, which is the slope of the rectilinear part of the curve.

For ultrastructural analysis, both injected and control NRK-cells were fixed in $2 \%$ glutaraldehyde and buffered with Na-cacodylate $(\mathrm{pH}$ 7.4). Cell culture dishes were post-fixed in $2 \% \mathrm{OsO}_{4}$ and dehydrated in graded alcohol solutions. Embedding was performed by filling Agar 100 resin into a gelatin cyclinder that was placed over the injected area. Ultra-thin sections were stained in uranyl acetate and lead citrate and viewed with a Phillips 300 electron microscope.

\section{Acknowledgements}

The technical assistance of Berit Hausvik is highly appreciated. We are grateful to Dr Timothy McDonnell for providing the bcl-2-vector, to Dr Tom Nolan for providing the $b c l-2$ gene in a retroviral transfection system and to David $\mathrm{H}$. Burgess for preparing the bi-biotinylated cytochrome $c$. The bcl-2 transfected Clone 8 cells were kindly provided by Drs Ragnhild Ahlgren and Tone Sandal. The authors gratefully acknowledge Ms. AC Hellerquist and Ms E Wakeman for their assistance with preparation of the manuscript. This study was supported by the Norwegian Cancer Society, the Novo Nordic Foundation, the Swedish Medical Research Counsil (03X-2471), the Swedish Cancer Society (Cancerfonden, 3829B96-01XAB) and Nordic Research Foundation (NoRFA).

\section{References}

Alam MK, Davison S, Siddiqui N, Norton JD and Murphy JJ (1997) Ectopic expression of $\mathrm{Bcl}-2$, but not $\mathrm{Bcl}-\mathrm{x}_{\mathrm{L}}$ rescues Ramos B cells from Fas-mediated apoptosis. Eur. J. Immunol. 27: 3485-3491

Alnemri ES, Livingston DJ, Nicholson DW, Salvesen G, Thornberry NA, Wong WW and Yuan J (1996) Human ICE/CED-3 protease nomenclature. Cell 87: 171 
Brustugun OT, Mellgren G, Gjertsen BT, Bjerkvig R and Døskeland SO (1995) Sensitive and rapid detection of $\beta$-galactosidase expression in intact cells by microinjection of fluorescent substrate. Exp. Cell. Res. 219: 372-378

Cheng EHY, Kirsch DG, Clem RJ, Ravi R, Kastan MB, Bedi A, Ueno K and Hardwick JM (1997) Conversion of Bcl-2 to a Bax-like death effector by caspases. Science 278: $1966-1968$

Duckett CS, Li F, Wang Y, Tomaselli KJ, Thompson CB and Armstrong RC (1998) Human IAP-like protein regulates programmed cell death downstream of $\mathrm{BCl}-{ }_{x \mathrm{~L}}$ and cytochrome c. Mol. Cell Biol. 18: 608-615

Gjertsen BT, Cressey LI, Ruchaud S, Houge G, Lanotte M and Døskeland SO (1994) Multiple apoptotic death types triggered through activation of separate pathways by cAMP and inhibitors of protein phosphatases in one (IPC leukemia) cell line.J. Cell Sci. 107: 3363-3377

Hampton MB, Zhivotovsky B, Slater AFG, Burgess DH and Orrenius S (1998) Importance of the redox state of cytochrome $c$ during caspase activation in cytosolic extracts. Biochem. J. 329: 95-99

$\mathrm{He} \mathrm{H,} \mathrm{Lam} \mathrm{M,} \mathrm{McCormick} \mathrm{TS} \mathrm{and} \mathrm{Distelhorst} \mathrm{CW} \mathrm{(1997)} \mathrm{Maintenance} \mathrm{of} \mathrm{calcium}$ homeostasis in the endoplasmic reticulum by Bcl-2. J. Cell Biol. 138: 1219-1228 Hengartner M (1997) Apoptosis. CED-4 is a stranger no more. Nature 388: 714-715 Hengartner M (1998) Death cycle and Swiss army knives. Nature 391: 441-442

Hockenbery DM, Nuñez G, Milliman C, Schreiber RD and Korsmeyer SJ (1990) Bcl-2 is an inner mitochondrial membrane protein that blocks programmed cell death. Nature 348: 334-336

Kharbanda S, Pandey P, Schofield L, Israels S, Roncinske R, Yoshida K, Bharti A, Yuan ZM, Saxena S, Weichselbaum R, Nalin C and Kufe D (1997) Role for Bcl-- $\mathrm{L}_{\mathrm{L}}$ as an inhibitor of cytosolic cytochrome caccumulation in DNA damage-induced apoptosis. Proc. Natl. Acad. Sci. USA 94: 6939-6942

Kluck RM, Bossy-Wetzel E, Green DR and Newmeyer DD (1997a) The release of cytochrome $c$ from mitochondria: A primary site for $\mathrm{Bcl}-2$ regulation of apoptosis. Science 275: 1132-1136

Kluck RM, Martin SJ, Hoffman BM, Zhou JS, Green DR and Newmeyer DD (1997b) Cytochrome $c$ activation of CPP32-like proteolysis plays a critical role in a Xenopus cell-free apoptosis system. EMBO J. 16: 4639-4649

Kroemer G (1997) Mitochondrial implication in apoptosis. Towards an endosymbiont hypothesis of apoptosis evolution. Cell Death Differ. 4: 443-456

Li P, Nijhawan D, Budihardjo I, Srinivasula SM, Ahmad M, Alnemri ES and Wang X (1997) Cytochrome $c$ and dATP-dependent formation of Apaf-1/Caspase-9 complex initiates an apoptotic protease cascade. Cell 91: 479-489

Li F, Srinivasan A, Wang Y, Armstrong RC, Tomaselli K and Fritz LC (1997) Cellspecific induction of apoptosis by microinjection of cytochrome $c$. Bcl- $\mathrm{X}_{\mathrm{L}}$ has activity independent of cytochrome crelease. J. Biol. Chem. 272: 30299-30305

Liu X, Kim NC, Yang J, Jemmerson R and Wang X (1996) Induction of apoptotic program in cell-free extracts: Requirement for dATP and cytochrome $c$. Cell 86: $147-157$
Mellgren G, Vintermyr OK, Bøe R and Døskeland SO (1993) Hepatocyte DNA replication is abolished by inhibitors selecting protein phosphatase $2 \mathrm{~A}$ rather than phosphatase 1. Exp. Cell. Res. 205: 293-301

$\mathrm{Ng}$ FWH and Shore GC (1998) Bcl- $\mathrm{K}_{\mathrm{L}}$ cooperatively associates with the Bap31 complex in the endoplasmic reticulum, dependent on procaspase-8 and Ced-4 adaptor. J. Biol. Chem. 273: 3140-3143

Nicotera P and Leist M (1997) Energy supply and the shape of death in neurones and lymphoid cells. Cell Death Differ. 4: 435-442

Reed JC (1997) Double identity for proteins of the Bcl-2 family. Nature 387: 773-776

Rosse T, Oliver R, Monney L, Rager M, Conus S, Fellay I, Jansen B and Borner C (1998) Bcl-2 prolongs cell survival after Bax-induced release of cytochrome $C$. Nature 391: $496-498$

Scaife JF (1966) The effect of lethal doses of X-irradiation on the enzymatic activity of mitochondrial cytochrome $c$. Canad J. Biochem. 44: 433-439

Takayama S, Bimston DN, Matsuzawa S, Freeman BC, Aime-Sempe C, Xie Z, Morimoto RI and Reed J (1997) Bag-1 modulates the chaperone activity of Hsp70/Hsc70. EMBO J. 16: 4887-4896

Tsujimoto Y (1997) Apoptosis and necrosis: intracellular ATP levels as a determinant for cell death modes. Cell Death Diff. 4: 429-434

Vander Heiden MG, ChandeINS, Williamson EK, Schumacker PT and Thompson CB (1997) Bcl-X $\mathrm{X}_{\mathrm{L}}$ regulates the membrane potential and volume homeostasis of mitochondria. Cell 91: 627-637

Wang HG, Rapp UR and Reed JC (1996a) Bcl-2 targets the protein kinase Raf-1 to mitochondria. Cell 87: 629-638

Wang HG, Takayama S, Rapp UR and Reed JC (1996b) Bcl-2 interacting protein, BAG-1, binds to and activates the kinase Raf-1. Proc. Natl. Acad. Sci. USA 93: 7063-7068

Yang J, Liu X, Bhalla K, Kim CN, Ibrado AM, Cai J, Peng T-I, Jones DP and Wang X (1997) Prevention of apoptosis by Bcl-2: Release of cytochrome $c$ from mitochondria blocked. Science 275: 1129-1131

Yang X, Chang HY and Baltimore D (1998) Autoproteolytic activation of procaspases by oligomerization. Molec. Cell 1: 319-325

Zhivotovsky B, Orrenius S, Brustugun OT and Døskeland SO (1998) Injected cytochrome $c$ induces apoptosis. Nature 391: 449-450

Zhivotovsky B, Burgess DH, Vanags DM and Orrenius S (1997) Involvement of cellular proteolytic machinery in apoptosis. Biochem. Biophys. Res. Commun. 230: $481-488$

Zou H, Henzel WJ, Liu X, Lutschg A and Wang X (1997) Apaf-1, a human protein homologous to $C$. elegans CED-4, participates in cytochrome $c$-dependent activation of caspase-3. Cell 90: 405-413 